\title{
Establishment of a Rapid and Efficient Micropropagation System for Succulent Plant Haworthia turgida Haw.
}

\author{
Boling Liu, Hongzhou Fang, Chaorong Meng, Ming Chen, \\ and Qingdong Chai \\ College of Life Sciences, Qufu Normal University, 273165, Qufu, Shandong, \\ China
}

\author{
Kai Zhang \\ Culaishan Forest Farm of Tai'an City, 271000, Tai'an, Shandong, China
}

Shijuan Liu' ${ }^{1}$

College of Life Sciences, Qufu Normal University, 273165, Qufu, Shandong, China

Additional index words. callus, plant growth regulators, propagation, root, shoot

\begin{abstract}
In the present study, the effect of plant growth regulators (PGRs) on callus regeneration, adventitious shoot differentiation, and root formation of Haworthia turgida Haw. was investigated. The greatest callus induction percentage $(95.6 \%)$ was achieved with leaf explants inoculated on Murashige and Skoog (MS) medium with $1.0 \mathrm{mg} \cdot \mathrm{L}^{-1}$ 6benzyladenine (BA) and $0.1 \mathrm{mg} \cdot \mathrm{L}^{-1}$ 1-naphthaleneacetic acid (NAA), and this callus induction medium supplemented with $2.5 \mathrm{mg} \cdot \mathrm{L}^{-1}$ thidiazuron (TDZ) was optimal for callus proliferation. The maximum number of shoots (25.7) was obtained when the callus was cultured on MS medium supplemented with $1.0 \mathrm{mg} \cdot \mathrm{L}^{-1} \mathrm{BA}$ and $0.2 \mathrm{mg} \cdot \mathrm{L}^{-1}$ 2,4dichlorophenoxyacetic acid (2,4-D). The highest number of roots per shoot (6.2) and highest rooting frequency $(82.0 \%)$ were obtained when adventitious shoots were inoculated on MS medium with $0.05 \mathrm{mg} \cdot \mathrm{L}^{-1} \mathrm{NAA}$. Regenerated plantlets were transferred to a mixture of vermiculite and soil and acclimated in a greenhouse. The survival rate of the transplanted plantlets was about $91.6 \%$. The rate of ex vitro rooting was $\mathbf{8 3 . 3 \%}$, indicating that this technique is effective for root induction in $\mathrm{H}$. turgida. This study has established a rapid and efficient micropropagation system that can be beneficial for commercial cultivation and germplasm conservation of $\boldsymbol{H}$. turgida.
\end{abstract}

The succulent plant genus Haworthia, belonging to the Liliaceae family, is native to South Africa, Namibia, Swaziland, and Mozambique (Beyl and Sharma, 1983; Kaul and Sabharwal, 1972). Haworthia exhibits highly variable yet distinct plant and leaf morphology, thus sparking the interest of both amateur botanists and succulent plant collectors. Haworthia has been used in pot culture and landscaping of open-air rockeries (Barker, 1929). Its species are well adapted to

\footnotetext{
Received for publication 26 Apr. 2017. Accepted for publication 26 July 2017.

This work was funded by the Natural Science Foundation of Shandong Province (ZR2014JL021), the Science and Technology Planning Project (xkj201403) and the Doctoral Scientific Fund Project of Qufu Normal University (bsqd20130136).

We appreciate Byoung Ryong Jeong (Department of Horticulture, College of Agriculture and Life Sciences, Gyeongsang National University, Jinju, Korea) for revising this manuscript.

Establishment of a Rapid and Efficient Micropropagation System for Succulent Plant Haworthia turgida Haw.

'Corresponding author. E-mail: sjliusj@163.com.
}

been considered as an attractive way of propagating Haworthia genus plants. This method facilitates the propagation of plants without seasonal and environment limitations and in a large scale, which are important factors in the breeding plants for ornamental and landscaping purposes (Kitamura et al., 2002; Kumari et al., 2016; Preil et al., 1988). Plantlets have been successfully induced in several Haworthia species using explants from inflorescences (Kaul and Sabharwal, 1972; Majumdar, 1970a; Ogihara, 1979; Ogihara and Tsunewaki, 1978), ovary walls (Majumdar, 1970b), and leaves (Beyl and Sharma, 1983; Rogers, 1993b). Growth characteristics in response to various auxins and cytokinins, such as NAA, 2,4-D, and BA (Kaul and Sabharwal, 1972; Ogihara, 1979; Ogihara and Tsunewaki, 1978), have been examined in some Haworthia species. However, none of these studies have used TDZ in in vitro propagation, although it is an efficient PGR and is widely used for rapid propagation of plant tissues (Fatima and Anis, 2011; Kitamura et al., 2002; Kumari et al., 2016; Murthy et al., 1998). To the best of our propagation knowledge, there has also been no published study on in vitro propagation of $H$. turgida through the leaf explants either. Therefore, the current study aimed to establish a rapid and efficient micropropagation protocol for $H$. turgida using the TDZ as a PGR and the leaves as explants.

\section{Materials and Methods}

Plant materials. Haworthia turgida plants were donated by the Institute of Botany, Chinese Academy of Sciences. Plants were transplanted in a greenhouse at College of Life Sciences, Qufu Normal University, China in July 2014. Fresh leaves were used as explants, which were washed in running tap water mixed with a few drops of liquid detergent for $30 \mathrm{~min}$. Then, the leaves were decontaminated with $70 \%$ ethanol for $30 \mathrm{~s}$ followed by two to three washes with sterile water. After decontamination, the explants were sterilized in $0.1 \% \mathrm{HgCl}_{2}$ supplemented with $0.05 \%$ Tween-20 for $5 \mathrm{~min}$, then washed with sterilized water for 3-4 times and dried with disinfected filter paper. The sterilized leaves were cut into $0.5-1.0 \mathrm{~cm}$ pieces for subsequent experiments after removing injured leaf bases using a sterilized blade.

Culture medium and culture conditions. The culture medium consisted of Murashige and Skoog (1962) basal salts and vitamins as base medium, mixed with $3 \%(\mathrm{w} / \mathrm{v})$ sucrose and solidified with $0.7 \%(\mathrm{w} / \mathrm{v})$ plant agar. The $\mathrm{pH}$ of the medium was adjusted to 5.8 using $0.1 \mathrm{M} \mathrm{NaOH}$ or $0.1 \mathrm{M} \mathrm{HCl}$, and the medium was autoclaved at $121^{\circ} \mathrm{C}$ for $20 \mathrm{~min}$. The MS medium was supplemented with PGRs before $\mathrm{pH}$ adjustment and sterilization. All cultures were placed at $24 \pm 1{ }^{\circ} \mathrm{C}$ under a $14-\mathrm{h}$ photoperiod with $40 \mu \mathrm{mol} \cdot \mathrm{m}^{-2} \cdot \mathrm{s}^{-1}$ photosynthetic photon density quipped with cool-white fluorescent lamps (Philips $40 \mathrm{~W}$ tubes).

Callus induction and propagation. The explants were inoculated on a basal MS 
medium with $0,1.0,2.0$, or $3.0 \mathrm{mg} \cdot \mathrm{L}^{-1} \mathrm{BA}$ in combination with $0,0.1,0.2$, or $0.5 \mathrm{mg} \cdot \mathrm{L}^{-1}$ NAA (Table 1) based on previous reports (Ogihara, 1979; Ogihara and Tsunewaki, 1978) on $H$. setata and $H$. aristata for induction of callus generation. Then callus was cut into $1-2 \mathrm{~cm}^{2}$ pieces and transferred to another medium supplemented with $0,0.5$, $1.0,1.5,2.0,2.5$, or $3.0 \mathrm{mg} \cdot \mathrm{L}^{-1} \mathrm{TDZ}$ (Table 2) for callus proliferation. In each treatment, 15 explants were used, and each experiment was repeated three times. Fresh callus weight of each treatment was recorded after $30 \mathrm{~d}$. Callus growth rate was calculated as using the following equation: Growth rate $=\left(w_{\mathrm{t}}-w_{0}\right) / w_{0}$, where $w_{\mathrm{t}}$ and $w_{0}$ are the final and initial fresh weight of each callus, respectively. The term "growth" is used to represent callus development as evaluated by fresh weight (Ogihara and Tsunewaki, 1978), and callus induction ratio was calculated as follows:

Callus induction ratio

$=($ Number of explanted leaves showing

callus formation $\left./ \begin{array}{l}\text { Total number of } \\ \text { explanted leaves }\end{array}\right) \times 100$

Adventitious shoot differentiation. Each callus was cut into small pieces of around $2 \mathrm{~cm}^{2}$ and transferred to the MS medium containing 0 , $1.0,2.0$, or $3.0 \mathrm{mg} \cdot \mathrm{L}^{-1} \mathrm{BA}$ in combination with $0,0.1,0.2$, or $0.5 \mathrm{mg} \cdot \mathrm{L}^{-1} 2,4-\mathrm{D}$ for adventitious shoot induction (Table 3 ). The number of callus-forming adventitious shoots and the average number of shoots per callus were recorded after $30 \mathrm{~d}$. In each treatment, 24 explants were used, and each experiment was repeated thrice.

Rooting of shoots and acclimatization. The elongated shoots $(2-3 \mathrm{~cm}$ in length) were inoculated on the MS medium with $0,0.05$, $0.10,0.15$, or $0.20 \mathrm{mg} \cdot \mathrm{L}^{-1} \mathrm{NAA}$ for root formation (Table 4). After $30 \mathrm{~d}$, the frequency of root induction, number of roots per plantlet, and length of the roots were assessed. In each treatment, 24 shoots were used, and each experiment was repeated thrice. Meanwhile, 60 elongated shoots (2-3 cm in length) were wounded gently at the bottom of the stem, and then transplanted to a mixture of vermiculite and soil (Flower Nutrition Soil, Deli, Fuzhou, China; 1:1, v/v), and established in the greenhouse for simultaneous ex vitro rooting. The rooting percentage was calculated as follows:

$$
\begin{aligned}
& \text { Rooting percentage } \\
& =(\text { Number of shoots with roots } / \\
& \quad \text { Total number of shoots planted }) \times 100
\end{aligned}
$$

Well-rooted plantlets were taken out from culture vessels, washed in running tap water to remove attached agar, transplanted in acclimatization boxes $(7 \times 7 \mathrm{~cm})$ with a mixture of vermiculite and flower nutrient soil $(1: 1, v / v)$, and placed in the greenhouse under a natural photoperiod condition and $25 \pm 2{ }^{\circ} \mathrm{C}$ and $70 \%$ relative humidity. Plantlet survival percentage was calculated after $30 \mathrm{~d}$ based on the following:

$$
\begin{aligned}
& \text { Plantlet survival percentage } \\
& =(\text { Number of live plantlets / Total number } \\
& \quad \text { of plantlets transplanted }) \times 100
\end{aligned}
$$

Statistical analysis. All percentage data were transformed using arcsine square root. The equation $P^{\prime}=$ ASIN(SQRTP) was used to normalize error distribution before variance analysis (Compton, 1994), then the percentage data were employed to express the original units. All data were analyzed statistically using a statistical software SPSS (version 19.0; IBM, Armonk, NY). Significant differences among the treatments were determined using the Duncan's multiple range test at $P<0.05$. The results were expressed as the mean \pm SE of repeated experiments.

\section{Results and Discussion}

Effect of NAA and BA on induction of callus from the leaf explants. PGRs such as auxins and cytokinins are the main regulators of plant de- and redifferentiation (Frello et al., 2002; Kordi et al., 2013; Liu et al., 2016; Peeters et al., 1991). Jaco et al. (1993) used BA and NAA for callus induction of sugar beet (Beta vulgaris). In this study, various types and concentration of PGRs were selected based on previous studies with some modifications (Kaul and Sabharwal, 1972; Kitamura et al., 2002; Ogihara, 1979; Ogihara and Tsunewaki, 1978). The leaf explants of $H$. turgida formed calli on all MS media supplemented with various concentrations of NAA and BA (Table 1). The explants started to differentiate at $20 \mathrm{~d}$ after the inoculation and formed reddish-colored calli (Fig. 1A). After $30 \mathrm{~d}$, yellow-green tumor-like calli started to form at the cutting edges (Fig. 1B). After $40 \mathrm{~d}$, green and compact callus formed in most of the explanted leaves and some globular shoot primordia were also observed (Fig. 1C). The greatest percentage of callus induction $(95.6 \%)$ was achieved when the leaf explants were inoculated on medium that contained $1.0 \mathrm{mg} \cdot \mathrm{L}^{-1} \mathrm{BA}$ and $0.1 \mathrm{mg} \cdot \mathrm{L}^{-1} \mathrm{NAA}$ (Table 1). Similar results were also reported in Kalanchoe blossfeldiana (Kordi et al., 2013).

Table 1. Effects of 1-naphthaleneacetic acid and 6-benzyladenine concentrations on callus induction from the leaf explants of Haworthia turgida. Data recorded after $40 \mathrm{~d}$.

\begin{tabular}{lccl}
\hline NAA $\left(\mathrm{mg} \cdot \mathrm{L}^{-1}\right)$ & BA $\left(\mathrm{mg} \cdot \mathrm{L}^{-1}\right)$ & Induction $(\%)$ & \multicolumn{1}{c}{ Notes } \\
\hline 0.0 & 0.0 & $10.9 \pm 2.20 \mathrm{~d}^{\mathrm{z}}$ & Rare individual explants developed into calli \\
0.1 & 1.0 & $95.6 \pm 3.84 \mathrm{a}$ & The explants developed yellowish green calli with compact texture and several globular structures \\
0.1 & 2.0 & $62.4 \pm 5.88 \mathrm{~b}$ & The explants developed yellowish green calli with a few yellow-green globular structures \\
0.1 & 3.0 & $37.7 \pm 2.23 \mathrm{c}$ & The explants developed a few calli \\
0.2 & 1.0 & $60.1 \pm 3.87 \mathrm{~b}$ & The explants developed yellowish green calli with a few yellow-green globular structures \\
0.2 & 2.0 & $57.8 \pm 2.23 \mathrm{~b}$ & The explants developed yellowish green calli with a few yellow-green globular structures \\
0.2 & 3.0 & $31.1 \pm 2.20 \mathrm{c}$ & The explants developed a few calli \\
0.5 & 1.0 & $39.9 \pm 3.87 \mathrm{c}$ & The explants developed a few calli \\
0.5 & 2.0 & $28.6 \pm 5.88 \mathrm{c}$ & The explants developed a few calli \\
0.5 & 3.0 & $24.4 \pm 2.23 \mathrm{c}$ & Few individual explants developed into calli \\
\hline
\end{tabular}

${ }^{\mathrm{z}}$ Means followed by the same letter(s) within a column are not significant at $P<0.05$. Values represent the mean \pm SE of three replications each with five explants. $\mathrm{BA}=6$-benzyladenine; NAA = 1-naphthaleneacetic acid.

Table 2. Effects of thidiazuron plus $1.0 \mathrm{mg} \cdot \mathrm{L}^{-1}$ 6-benzyladenine and $0.1 \mathrm{mg} \cdot \mathrm{L}^{-1} 1$-naphthaleneacetic acid on the growth rate of callus of $H$. turgida. Data recorded after $30 \mathrm{~d}$.

\begin{tabular}{lcl}
\hline TDZ $\left(\mathrm{mg} \cdot \mathrm{L}^{-1}\right)$ & Growth rate $($ fold $)$ & Notes \\
\hline 0.0 & $1.15 \pm 0.04 \mathrm{~d}^{\mathrm{z}}$ & Callus formation was slowly induced \\
0.5 & $1.95 \pm 0.05 \mathrm{c}$ & Callus formation was slowly induced and showed compact texture \\
1.0 & $2.29 \pm 0.04 \mathrm{c}$ & Callus formation was induced and showed a compact texture \\
1.5 & $2.37 \pm 0.08 \mathrm{c}$ & Callus formation was induced and showed a compact texture \\
2.0 & $2.90 \pm 0.13 \mathrm{~b}$ & Callus formation was induced and showed a fragile globular morphology \\
2.5 & $4.07 \pm 0.36 \mathrm{a}$ & Callus formation with the highest induction rate and development of a fragile globular morphology \\
3.0 & $3.69 \pm 0.08 \mathrm{a}$ & Callus formation was rapidly induced and development of a fragile globular morphology \\
\hline${ }^{\mathrm{z} M e a n s}$ followed by the same letter(s) within a column are not significant at $P<0.05$ Values represent the mean \pm SE of three replications each with five explants
\end{tabular}

$\mathrm{TDZ}=$ thidiazuron. 
Table 3. Effects of 6-benzyladenine and 2,4-dichlorophenoxyacetic acid on adventitious shoot induction from callus of $H$. turgida. Data recorded after $30 \mathrm{~d}$.

\begin{tabular}{|c|c|c|c|c|}
\hline$\overline{\mathrm{BA}\left(\mathrm{mg} \cdot \mathrm{L}^{-1}\right)}$ & 2,4-D $\left(\mathrm{mg} \cdot \mathrm{L}^{-1}\right)$ & Induction $(\%)$ & No. of shoots/callus & Description of growing status \\
\hline$\overline{0.0}$ & 0.0 & $8.0 \pm 2.40 \mathrm{~d}^{2}$ & $4.3 \pm 0.33 \mathrm{~h}$ & Few shoots were obtained \\
\hline 1.0 & 0.2 & $76.6 \pm 3.67 \mathrm{a}$ & $25.7 \pm 0.67 \mathrm{a}$ & $\begin{array}{l}\text { Cluster shoot formation was induced; shoots were thick and strong; fast } \\
\text { growing; with grass green color }\end{array}$ \\
\hline 2.0 & 0.1 & $23.4 \pm 3.67 \mathrm{c}$ & $12.7 \pm 0.67 \mathrm{e}$ & $\begin{array}{l}\text { Adventitious shoot formation was induced; yellow-green in color and } \\
\text { slender in shape }\end{array}$ \\
\hline 2.0 & 0.2 & $29.1 \pm 2.40 \mathrm{c}$ & $17.3 \pm 0.33 \mathrm{~d}$ & Adventitious shoot formation was induced; light-green in color \\
\hline 3.0 & 0.1 & $27.8 \pm 1.38 \mathrm{c}$ & $15.3 \pm 0.33 \mathrm{~d}$ & $\begin{array}{l}\text { Adventitious shoot formation was induced; yellow-green in color and } \\
\text { slender in shape }\end{array}$ \\
\hline 3.0 & 0.2 & $11.0 \pm 1.39 \mathrm{~d}$ & $8.3 \pm 0.37 \mathrm{f}$ & Few shoots were induced \\
\hline 3.0 & 0.5 & $9.6 \pm 1.39 \mathrm{~d}$ & $6.0 \pm 0.58 \mathrm{~g}$ & Few shoots were obtained \\
\hline
\end{tabular}

${ }^{\mathrm{z}}$ Means followed by the same letter(s) within a column are not significant at $P<0.05$.Values represent the mean \pm SE of three replications each with eight explants. $\mathrm{BA}=$ 6-benzyladenine; 2,4-D = 2,4-dichlorophenoxyacetic acid.

Table 4. Effect of 1-naphthaleneacetic acid on root induction in micropropagated plantlets of $H$. turgida. Data recorded after $30 \mathrm{~d}$.

\begin{tabular}{lccc}
\hline NAA $\left(\mathrm{mg} \cdot \mathrm{L}^{-1}\right)$ & Root induction (\%) & Avg no. of roots induced per shoot & Avg root length $(\mathrm{cm})$ \\
\hline 0.00 & $76.4 \pm 1.39 \mathrm{a}^{\mathrm{z}}$ & $4.9 \pm 0.38 \mathrm{~b}$ & $3.2 \pm 0.19 \mathrm{a}$ \\
0.05 & $82.0 \pm 1.39 \mathrm{a}$ & $6.2 \pm 0.42 \mathrm{a}$ & $2.6 \pm 0.29 \mathrm{ab}$ \\
0.10 & $62.5 \pm 2.40 \mathrm{~b}$ & $3.5 \pm 0.34 \mathrm{c}$ & $2.0 \pm 0.27 \mathrm{bc}$ \\
0.15 & $44.4 \pm 2.70 \mathrm{c}$ & $2.8 \pm 0.25 \mathrm{~cd}$ & $1.7 \pm 0.26 \mathrm{~cd}$ \\
0.20 & $33.3 \pm 2.40 \mathrm{~d}$ & $1.9 \pm 0.23 \mathrm{~d}$ & $1.3 \pm 0.16 \mathrm{~d}$ \\
\hline
\end{tabular}

${ }^{\mathrm{z}}$ Means followed by the same letter(s) within a column are not significant at $P<0.05$.

Values represent the mean \pm SE of three replications each with eight explants.

$\mathrm{NAA}=1$-naphthaleneacetic acid
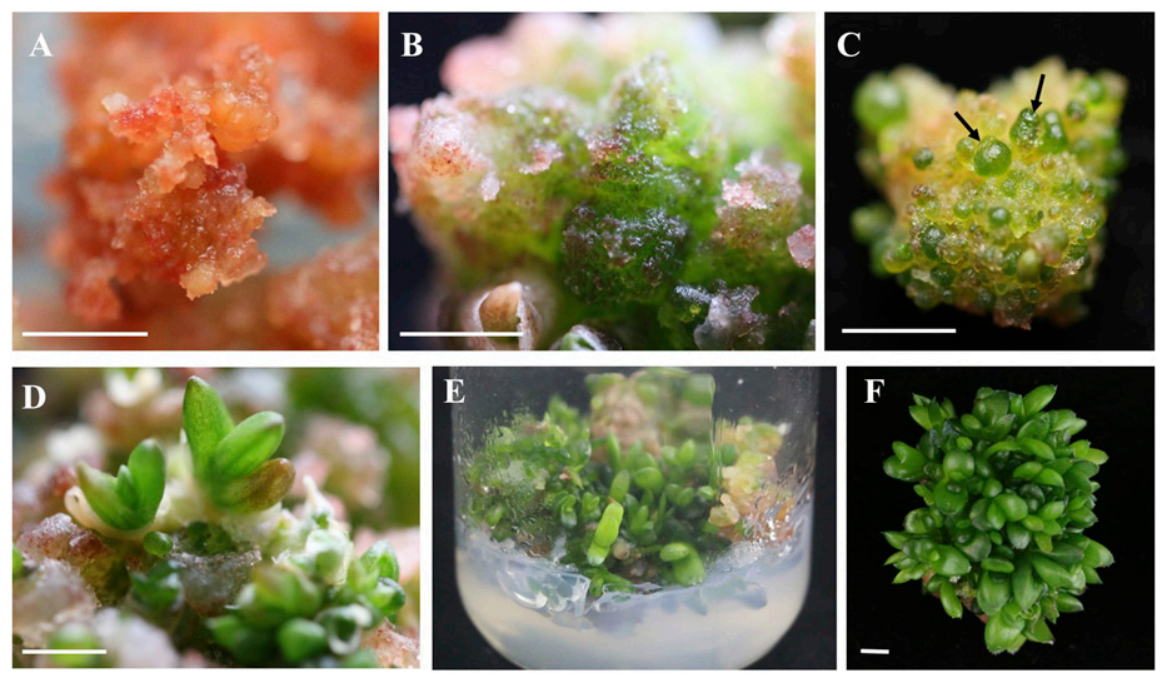

Fig. 1. Callus formation and adventitious shoot induction in Haworthia turgida. (A) reddish callus developed from the leaf explants on the Murashige and Skoog (MS) medium supplemented with 1.0 $\mathrm{mg} \cdot \mathrm{L}^{-1}$ 6-benzyladenine (BA) and $0.1 \mathrm{mg} \cdot \mathrm{L}^{-1} 1$-naphthaleneacetic acid, (B) the color of callus changed from red to green, (C) Callus with green shoot primordia (arrows), (D) induction of adventitious shoots on the MS medium supplemented with $1.0 \mathrm{mg} \cdot \mathrm{L}^{-1} \mathrm{BA}$ and $0.2 \mathrm{mg} \cdot \mathrm{L}^{-1}$ 2,4-dichlorophenoxyacetic acid, and $(\mathbf{E}$ and $\mathbf{F})$ proliferation of adventitious shoots. Scale bars $=0.5 \mathrm{~cm}$.

Effect of TDZ on callus redifferentiation. TDZ facilitates callus formation in various plant culture systems. It induces high cell proliferation rates compared with other PGRs (Jain and Rashid, 2001; Murthy et al., 1998). In some recalcitrant woody plants, TDZ stimulates callus formation at concentrations higher than $1 \mu \mathrm{M}$ (Huetteman and Preece, 1993). In Withania somnifera tissue cultures, high concentrations of TDZ $(8-20 \mu \mathrm{M})$ efficiently induce the formation of both callus and adventitious shoots (Sharma et al., 2014). Zhang et al. (2004) indicated that TDZ is more effective than BA in sugar beet regeneration. The present study showed that calli elicit different growth rate responses to various TDZ concentrations with $1.0 \mathrm{mg} \cdot \mathrm{L}^{-1}$ $\mathrm{BA}$ and $0.1 \mathrm{mg} \cdot \mathrm{L}^{-1} \mathrm{NAA}$ in MS medium. We observed that the growth rate increases with higher TDZ concentration, reaching the highest rate of proliferation ( $4.07 \pm 0.36$ fold), followed by a decrease. The highest callus growth rate was observed on MS medium containing $2.5 \mathrm{mg} \cdot \mathrm{L}^{-1} \mathrm{TDZ}, 1.0 \mathrm{mg} \cdot \mathrm{L}^{-1} \mathrm{BA}$, and $0.1 \mathrm{mg} \cdot \mathrm{L}^{-1} \mathrm{NAA}$, which may possibly be due to the optimal cytokinin activity of TDZ (Sivanesan et al., 2011). Calli appeared as transparent green particles or lumps with a compact or fragile organization, some of them containing shoot primordia (data not shown).

Effect of BA and 2,4-D on adventitious shoot regeneration from callus. Adventitious shoot proliferation in many succulent plants relies on the crosstalk between auxins and cytokinins (Amoo et al., 2009; Kitamura et al., 2002; Solís et al., 2013; Zhao et al., 2013). The leaf explants of Cotyledon orbiculata form adventitious shoots from calli on the medium supplemented with combinations of PGRs, among which BA with NAA, and TDZ with NAA were the optimal combinations (Kumari et al., 2016). In the present study, multiple adventitious shoots were induced from calli on MS medium using various concentrations of $\mathrm{BA}$ and 2,4-D (Table 3). Shoots initiation from green compact calli was detected at about $12 \mathrm{~d}$ of culture. After 3 weeks, adventitious shoots were observed with normal green leaves (Fig. 1D). Among the PGRs tested, the greatest induction ratio $(76.6 \%)$ of shoot regeneration and number of shoots $(25.7 \pm 0.67)$ were observed on MS medium contained $1.0 \mathrm{mg} \cdot \mathrm{L}^{-1} \quad \mathrm{BA}$ and $0.2 \mathrm{mg} \cdot \mathrm{L}^{-1} \quad 2,4-\mathrm{D}$ (Fig. 1E and F). This result is in line with the report that BA together with 2,4-D can induce shoot primordia from the surface of the callus of Curcuma longa (Salvi et al., 2001). This study showed that the combination of BA and 2,4-D significantly improves shoot formation. However, it could not induce multiple shoots when the callus was placed on the MS medium with a combination of BA and NAA (data not shown). We also observed that subculturing adventitious shoots of $H$. turgida allows these to continue producing more shoots. Because adventitious shoot regeneration is a relatively long process, the use of this method can save time and resources.

Effect of NAA on rooting and acclimatization. Generally, auxins such as NAA, IBA, and IAA that are added to the medium induce rooting (Sivanesan et al., 2011). Previous 


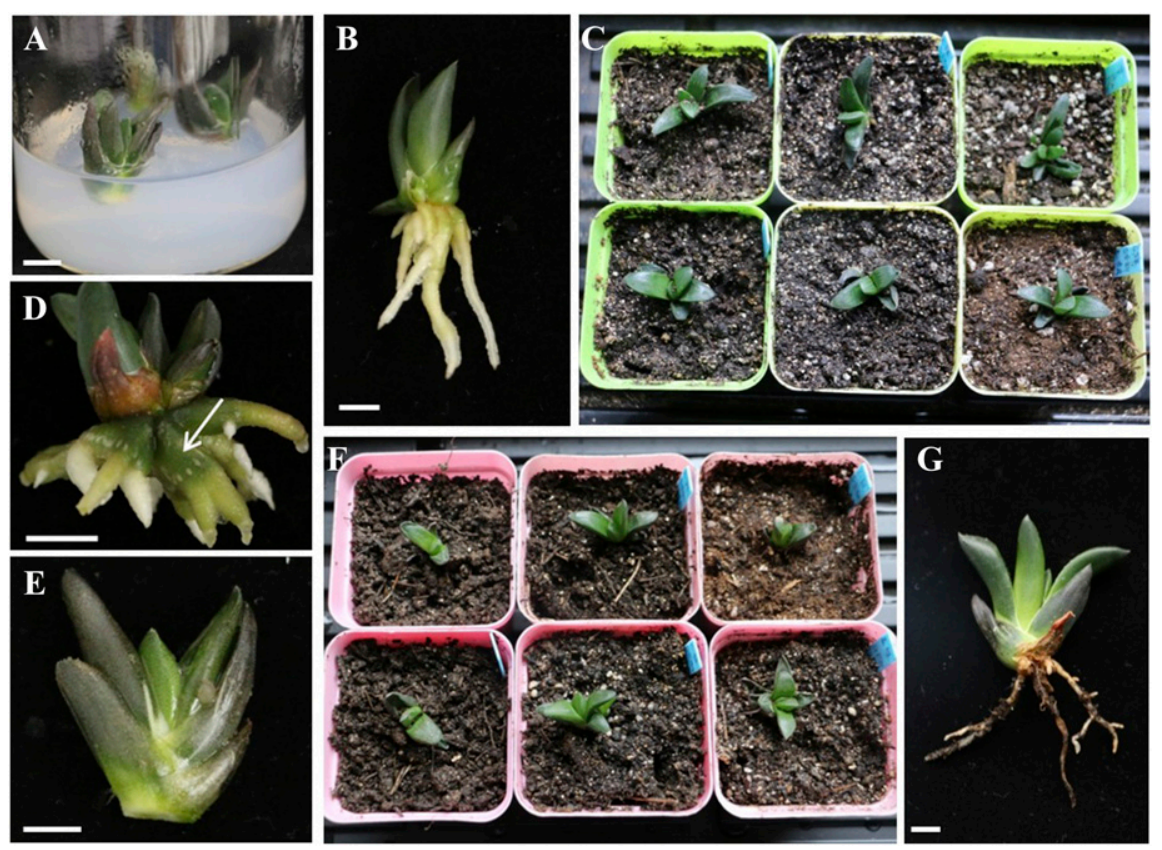

Fig. 2. In vitro and ex vitro rooting, and acclimatization of Haworthia turgida. (A) In vitro rooting on the Murashige and Skoog (MS) medium supplemented with $0.05 \mathrm{mg} \cdot \mathrm{L}^{-1} 1$-naphthaleneacetic acid (NAA), (B) in vitro root system, $(\mathbf{C})$ transplantation of in vitro-rooted plantlets, (D) Abnormal roots induced from MS medium with $0.15 \mathrm{mg} \cdot \mathrm{L}^{-1}$ or $0.20 \mathrm{mg} \cdot \mathrm{L}^{-1} \mathrm{NAA},(\mathbf{E})$ shoots before ex vitro rooting, $(\mathbf{F}) \mathrm{ex}$ vitro rooting in the mixture of vermiculite and soil $(1: 1, \mathrm{v} / \mathrm{v})$, and $(\mathbf{G})$ ex vitro rooting system. Scale bars $=0.5 \mathrm{~cm}$

reports have shown that the largest number of roots in Aloe vera could be achieved by culturing in a medium supplemented with $1 \mathrm{mg} \cdot \mathrm{L}^{-1}$ NAA (Hashem and Kaviani, 2010). The positive effect of NAA on both root induction and root elongation was demonstrated at a concentration of $0.5 \mathrm{mg} \cdot \mathrm{L}^{-1}$ on Kalanchoe blossfeldiana (Kordi et al., 2013). In the present study, elongated shoots $(2-3 \mathrm{~cm}$ in length) were inoculated on rooting medium with different concentrations of NAA in Table 4 (Fig. 2A). The greatest rooting percentage $(82.0 \%)$, number of roots $(6.2 \pm 0.42)$, and length of root $(2.6 \pm 0.29)$ per shoot were achieved on MS medium with $0.05 \mathrm{mg} \cdot \mathrm{L}^{-1}$ NAA, although number of shoots $(4.9 \pm 0.38)$ and longer roots $(3.2 \pm 0.19 \mathrm{~cm})$ were produced on MS medium without NAA supplementation (Table 4). Furthermore, roots showing abnormal morphology were observed when the concentration of NAA was increased to 0.15 or $0.2 \mathrm{mg} \cdot \mathrm{L}^{-1}$ (Fig. 2D). After $30 \mathrm{~d}$, healthy and well-rooted plantlets from the rooting medium were successfully transplanted (average $91.6 \%$ ) to a mixture of vermiculite and flower nutrient $(1: 1, \mathrm{v} / \mathrm{v})$ soil in the greenhouse (Fig. 2C).

Ex vitro rooting was obtained from the elongated adventitious shoots $(2-3 \mathrm{~cm}$ in length) (Fig. 2E and F). The root system was visible after $30 \mathrm{~d}$, with an average rooting percentage of $83.3 \%$, and the roots showed normal morphology compared with those induced from the rooting medium with $0.15 \mathrm{mg} \cdot \mathrm{L}^{-1}$ or $0.2 \mathrm{mg} \cdot \mathrm{L}^{-1} \mathrm{NAA}$ (Fig. $2 \mathrm{G}$ ). The use of ex vitro rooting reduced of the total cost of plant propagation by $35 \%$ to $75 \%$ (Debergh and Maena, 1981; Rajeswari and
Paliwal, 2008). The reduction in labor, time, and cost and the induction of better quality roots in the shoots indicated that ex vitro rooting is the most effective method for root induction in $H$. turgida. Healthy regenerated plantlets grew normally and were identical to parent plants with special translucent leaves with lines, which are known as the windowleaved plants (Krulik, 1980). Thus, this micropropagation protocol could facilitate in the propagation of $H$. turgida for commercial cultivation, as well as germplasm conservation.

\section{Literature Cited}

Amoo, S.O., J.F. Finnie, and J.V. Staden. 2009. In vitro propagation of Huernia hystrix: An endangered medicinal and ornamental succulent. Plant Cell Tissue Organ Cult. 96:273-278.

Barker, W.F. 1929. Haworthia. J. Bot. Soc. South Africa 11:22-24.

Beyl, C.A. and G.C. Sharma. 1983. Picloram induced somatic embryogenesis in Gasteria and Haworthia. Plant Cell Tissue Organ Cult. 2:123-132.

Compton, M.E. 1994. Statistical methods suitable for the analysis of plant tissue culture data. Plant Cell Tissue Organ Cult. 37:217-242.

Debergh, P.C. and L.J. Maena. 1981. A scheme of commercial propagation of ornamental plants by tissue culture. Sci. Hort. 14:335-345.

Egbert, K.J. and C.E. Martin. 2002. The influence of leaf windows on the utilization and absorption of radiant energy in seven desert succulents. Photosynthetica 40:35-39.

Fatima, N. and M. Anis. 2011. Thidiazuron induced high frequency axillary shoot multiplication in Withania somnifera L. Dunal. J. Med. Plants Res. 5:6681-6687.
Frello, S., E. Venerus, and M. Serek. 2002. Regeneration of various species of Crassulaceae, with special reference to Kalanchö̈. J. Hort. Sci. Biotechnol. 77:204-208.

Hashem, A.D. and B. Kaviani. 2010. In vitro proliferation of an important medicinal plant Aloe-A method for rapid production. Austral. J. Crop Sci. 4:216-222.

Huetteman, C.A. and J.E. Preece. 1993. Thidiazuron: A potent cytokinin for woody plant tissue culture. Plant Cell Tissue Organ Cult. 33:105119.

Jaco, B., T. Tetu, R.S. Sangwani, A.D. Laat, and B.S. Sangwan-Norreel. 1993. Efficient production of uniform plants from cotyledon explants of sugarbeet (Beta vulgaris L.). Plant Breed. 110:185-191.

Jain, P. and A. Rashid. 2001. Stimulation of shoot regeneration on Linum hypocotyl segments by thidiazuron and its response to light and calcium. Biol. Plant. 44:611-613.

Kaul, K. and P.S. Sabharwal. 1972. Morphogenetic studies on Haworthia: Establishment of tissue culture and control of differentiation. Amer. J. Bot. 59:377-385.

Kitamura, Y., K. Kubo, L. Rahman, and T. Ikenaga. 2002. Reproduction of Sedum drymarioides, an endangered rare species, by micropropagation. Plant Biotechnol. 19:303-309.

Kordi, M., B. Kaviani, and D. Hashemabadi. 2013. In vitro propagation of Kalanchoe blossfeldiana using BA and NAA. Eur. J. Expt. Biol. 3:285-288.

Krulik, G.A. 1980. Light transmission in windowleaved plants. Can. J. Bot. 58:1591-1600.

Kumari, A., P. Baskaran, and J.V. Staden. 2016. In vitro propagation and antibacterial activity in Cotyledon orbiculata: A valuable medicinal plant. Plant Cell Tissue Organ Cult. 124:97-104.

Liu, B.-L., Y. Zhang, K. Zhang, H.-Z. Fang, X.-M. Zhang, R. Fu, X.-H. Qiu, and R. Xu. 2016. The efficient tissue culture system of Orostachys fimbriata. Agr. Sci. 7:175-180.

Majumdar, S.K. 1970a. Culture of Haworthia inflorescences in vitro. J. South Afri. Bot. 36:63-67.

Majumdar, S.K. 1970b. Production of plantlets from the ovary wall of Haworthia turgida var. pallidifolia. Planta 90:212-214.

Murashige, T. and F. Skoog. 1962. A revised medium for rapid growth and bioassays with tobacco tissue cultures. Physiol. Plant. 15:473-497.

Murthy, B.N.S., S.J. Murch, and P.K. Saxena. 1998. Thidiazuron: A potent regulator of in vitro plant morphogenesis. In Vitro Cell. Dev. Biol. Plant 34:267-275

Mycock, D.J., M.P. Watt, K.F. Hannweg, K Naicker, M. Makwareka, and P. Berjak. 1997. Somatic embryogenesis of two indigenous South African Haworthia spp. (H. limifolia and H. koelmaniorum). S. Afr. J. Bot. 63:345-350.

Ogihara, Y. 1979. Tissue culture in Haworthia. II. Effects of three auxins and kinetin on greening and redifferentiation of calluses. Bot. Mag. Tokyo 92:163-171.

Ogihara, Y. and K. Tsunewaki. 1978. Tissue culture in Haworthia. I. Effects of auxins and kinetin on callus growth. Bot. Mag. Tokyo 91:83-91.

Peeters, A.J.M., W. Gerards, G.W.M. Barendse, and G.J. Wullems. 1991. In vitro flower bud formation in tobacco: Interaction of hormones. Plant Physiol. 97:402-408.

Preil, W., P. Florek, U. Wix, and A. Beck. 1988. Toward mass propagation by use of bioreactors. Acta Hort. 226:99-106.

Rajeswari, V. and K. Paliwal. 2008. In vitro plant regeneration of red sanders (Pterocarpus santalinus L.f.) from cotyledonary nodes. Indian J. Biotechnol. 7:541-546. 
Rogers, S.M.D. 1993a. Culture phenotype affects on regeneration capacity in the monocot Haworthia comptoniana. In Vitro Cell. Dev. Biol. Plant 29:9-12.

Rogers, S.M.D. 1993b. Optimization of plant regeneration and rooting from leaf explants of five rare Haworthia. Sci. Hort. 56:157-161.

Salvi, N.D., L. George, and S. Eapen. 2001. Plant regeneration from leaf base callus of turmeric and random amplified polymorphic DNA analysis of regenerated plants. Plant Cell Tissue Organ Cult. 66:113-119.
Sharma, N., E.P. Koshy, and M. Dhiman. 2014. TDZ induced multiple shoot regeneration and in vitro flowering from nodal explants in Withania somnifera. Intl. J. Sci. Res. 3:50-52.

Sivanesan, I., J.Y. Song, S.J. Hwang, and B.R. Jeong. 2011. Micropropagation of Cotoneaster wilsonii Nakai - A rare endemic ornamental plant. Plant Cell Tissue Organ Cult. 105:55-63.

Solís, J.J., M. Reyna, M. Feria, M.A. Cardona, and D. Rojas. 2013. In vitro propagation of Echeveria elegans, a species of the flora endangered Mexican. J. Environ. Sci. Eng. B 2:555-558. van Jaarsveld, E. 1999. Indigenous succulent plants for indoors. Veld Flora 6:82-84.

Zhang, C.L., D.F. Chen, M.C. Elliott, and A. Slater. 2004. Efficient procedures for callus induction and adventitious shoot organogenesis in sugar beet (Beta vulgaris L.) breeding lines. In Vitro Cell. Dev. Biol. Plant 40:475481.

Zhao, Y., A.R. Stiles, P.K. Saxena, and C.-Z. Liu. 2013. Dark preincubation improves shoot organogenesis from Rhodiola crenulata leaf explants. Biol. Plant. 57:189-192. 